\title{
Maintenance of functional corpora lutea in androgenized female rats treated with PMSG
}

\author{
D. C. Johnson \\ Departments of Gynecology \& Obstetrics and Physiology, Ralph L. Smith Research Center, \\ University of Kansas Medical Center, Kansas City, Kansas 66103, U.S.A.
}

\begin{abstract}
Summary. Rats were androgenized by injection of $50 \mu \mathrm{g}$ testosterone propionate on the 5th day after birth and when adult were treated with 5 i.u. PMSG; some of the animals were mated. Serum was obtained daily and the concentrations of progesterone, 20 $\alpha$-dihydroprogesterone and prolactin, estimated by radioimmunoassays, were compared to values found for mated, but not ovulating, androgenized females and those for normal pregnant females.

Ovulation and luteinization of follicles occurred. The concentration of progesterone increased after the injection of PMSG and remained elevated for at least 10 days; mating did not alter the progesterone levels. The concentration of $20 \alpha$-dihydroprogesterone was also elevated but the ratio of the level of progesterone to this steroid was generally greater than unity. Prolactin levels were elevated in the rats which ovulated. It is concluded that the corpora lutea induced in androgenized females by PMSG are functional and maintained.
\end{abstract}

\section{Introduction}

Adult female rats androgenized neonatally by treatment with testosterone propionate typically display a cornified vaginal mucosa, which is the basis for calling them 'constant oestrous' animals (Segal \& Johnson, 1959; Barraclough, 1961; Johnson, 1972). Such females can also be considered in 'constant pro-oestrus', considering the ovarian follicular development and the elevated concentrations of oestradiol in the serum (Cheng \& Johnson, 1973/74; Mallampati \& Johnson, 1974). Ovulation, formation of corpora lutea, and interruption of the condition of vaginal oestrus follow a 'surge' in gonadotrophins in these animals whether it is accomplished by injection of exogenous FSH and LH or by administration of hypothalamic gonadotrophinreleasing hormone (Segal \& Johnson, 1959; Johnson, 1963). Progesterone production, presumably from corpora lutea, begins shortly after the induction of ovulation but it does not persist (Barraclough \& Fajer, 1968; Pang \& Johnson, 1974). Barraclough \& Fajer (1968) considered this failure to establish pseudopregnancy a consequence of inadequate prolactin secretion from the pituitary of the androgenized female.

The gonadotrophin surge in the oestrous cycle of the normal rat has been shown to consist of a relatively brief but large rise in the concentration of $\mathrm{LH}$ in the serum and a more sustained rise in FSH (Gay, Midgley \& Niswender, 1970; Butcher, Collins \& Fugo, 1974; Smith, Freeman \& Neill, 1975). Pseudopregnancy with persistence of ovarian progesterone production can be induced either by mating or mechanical stimulation of the uterine cervix at the time of the gonadotrophin surge; the latter procedure is known to lead to secretion of prolactin from the pituitary (Smith, McLean \& Neill, 1976).

The objective of the present study was to induce pseudopregnancy or pregnancy in androgenized female rats injected with PMSG. This gonadotrophin was chosen because of its long half-life which produces a rise in FSH and LH activity persisting for several hours. 


\section{Materials and Methods}

Animals

Holtzman-strain female rats were injected (s.c.) with $50 \mu \mathrm{g}$ testosterone propionate (Sigma Chemical Co., St. Louis, Missouri) dissolved in $0.5 \mathrm{ml}$ sesame-seed oil, on the 5th day after birth; litters were reduced to 8 young at this time. The animals were weaned when $21-23$ days old and groups of 4 females were caged together until they were 60-90 days old. Constant oestrus was confirmed for each animal by daily vaginal smears for 7 days.

Samples of blood $(0.75 \mathrm{ml})$ were obtained from the tail vein of each female, lightly anaesthetized with ether, on alternate days. The entire bleeding procedure was completed in 60 $90 \mathrm{sec}$. The blood was allowed to clot at room temperature, centrifuged at $2000 \mathrm{~g}$ for $20 \mathrm{~min}$ and the serum was separated and frozen. Terminal blood samples were obtained following decapitation; the ovaries were removed and examined for the presence of corpora lutea.

To establish normal laboratory values, 10 non-androgenized females were bled at various times during the first half of pregnancy; Day 1 of pregnancy was taken as the day spermatozoa were found in the vaginal lavage. Blood samples were obtained from a group of 5 rats at 10:00 h (lights on from 06:00 to 20:00 h) such that each animal was bled usually only every 4 days but not more often than every other day.

When the androgenized females were to be mated they were placed on an altered light-dark schedule 10 days before use. The lights were off from 10:00 to 20:00 h each day. PMSG, 5 i.u. (Sigma Chemical Co., St. Louis, Missouri; 2500 i.u./mg), was injected i.v., using light ether anaesthesia, $1 \mathrm{~h}$ before the beginning of the dark period. Mating was allowed during the $3 \mathrm{rd}$ to 7 th hours of darkness. After mating two groups of 4 rats each were bled on alternate days at 10:00 h (time of lights out) and 2 groups were bled on alternate days at 16:00 h (i.e. $6 \mathrm{~h}$ into the dark period). One group of 10 androgenized females was mated but not given PMSG; 5 animals of this group were bled each day thereafter.

Another group of androgenized females was maintained on a light schedule of 06:00 to 20:00 h each day. These animals were injected with 5 i.u. PMSG but were not mated; Blood samples were obtained from some animals every day thereafter.

Assays

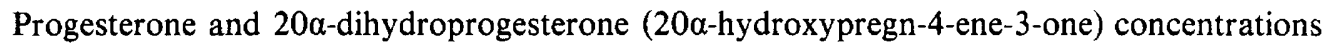
were determined by radioimmunoassay. Anti-progesterone antiserum was prepared by $\mathrm{Dr}$ Vernon Stevens (Ohio State University, Columbus, Ohio). This antibody showed a $4 \%$ crossreactivity with $17 \alpha$-hydroxyprogesterone and a $20 \%$ cross-reactivity with $5 \alpha$-pregnen-3,20-dione but cross-reactions with other progestagens, androgens or oestrogens were less than $0 \cdot 1 \%$. The antiserum to $20 \alpha$-dihydroprogesterone was prepared by $\mathrm{Dr}$ C. N. Pang and Dr J. Hilliard (University of California at Los Angeles) and the only steroid which gave appreciable crossreactivity, i.e. $>1 \%$, was $20 \beta$-dihydroprogesterone (42\%). A detailed description of the assay procedure has been published (Grotjan \& Johnson, 1976). All standards were extracted from serum obtained from adult adrenalectomized and ovariectomized rats; no correction for extraction efficiency, which averaged $83 \pm 2 \cdot 5 \%$, was made. The minimal detectable amounts were $10 \mathrm{pg}$ progesterone and $5 \mathrm{pg} 20 \alpha$-dihydroprogesterone. While the antisera were highly specific for the hormones studied cross-reactivities with other steroids were unavoidable and values stated for progesterone and $20 \alpha$-dihydroprogesterone may include other materials extracted by the methods used. All samples from the same series were included in the same assay; intra- and interassay coefficients of variation have consistently remained below 10 and $20 \%$ respectively.

Prolactin was measured using the radioimmunoassay kits supplied by the National Institute of Arthritis, Metabolism and Digestive Diseases, U.S. Public Health Service. Rat prolactin (I-2) 
was iodinated by a modification of the method described by Butt (1972). The important modification was use of a $1 \times 2 \mathrm{~cm}$ round plastic cup filled with paraffin wax as the iodination vessel. Prolactin $(2.5 \mu \mathrm{g}$ in $25 \mu \mathrm{l})$ was placed in a centre depression in the wax along with $25 \mu \mathrm{l}$ $0.5 \mathrm{M}$-sodium phosphate $(\mathrm{pH} 7.2)$ and $300 \mu \mathrm{Ci}(3 \mu \mathrm{l}) \mathrm{Na}^{125}$ ( New England Nuclear Corp., Boston, Massachusetts). The cup was covered with a glass slide to which was attached a piece of filter paper $(2 \mathrm{~cm}$ diam. $)$ which has been soaked with a solution of chloramin-T $(8 \mathrm{mg} / \mathrm{ml})$; the filter paper had previously been impregnated with $0.15 \mathrm{M}-\mathrm{NaCl}$ and dried. The iodination was allowed to proceed for $6 \mathrm{~min}$ and then the iodinated hormone was separated on Sephadex G-75 by using $0.1 \mathrm{M}$-phosphate buffer, $\mathrm{pH} 7.2$, for elution. In the assays the results were expressed in terms of the standard supplied with the kit (RP-1). The minimal concentration of prolactin detectable was $0.6 \mathrm{ng} / \mathrm{ml}$ with an inter-assay coefficient of variation of $6.2 \pm 1$ (s.e.m.) \%; intraassay variation was $13 \cdot 8 \pm 1.6 \%$.

\section{Results}

The concentrations of progesterone, 20a-dihydroprogesterone and prolactin, found in normal pregnant females at 10:00 h (lights on 06:00-20:00 h daily) are shown in Table 1. Progesterone levels continued to rise until Day 10 but $20 \alpha$-dihydroprogesterone levels continually declined after Day 3. Prolactin concentrations were generally low, but variable, particularly on Days 6 and 12. All of these animals delivered normal litters (8-13 young) on Days 22 or 23 of pregnancy.

Table 1. Mean \pm s.e.m. concentrations of progesterone, 20a-dihydroprogesterone (20a-OHP) and prolactin in the sera of normal pregnant rats (4-6/group)

\begin{tabular}{|c|c|c|c|c|}
\hline $\begin{array}{l}\text { Day of } \\
\text { pregnancy* }\end{array}$ & $\begin{array}{l}\text { Progesterone } \\
(\mathrm{ng} / \mathrm{ml})\end{array}$ & $\begin{array}{c}20 \mathrm{a}-\mathrm{OHP} \\
(\mathrm{ng} / \mathrm{ml})\end{array}$ & $\begin{array}{c}\text { Ratio of } \\
\text { progesterone : } 20 \alpha-\mathrm{OHP}\end{array}$ & $\begin{array}{l}\text { Prolactin } \\
(\mathrm{ng} / \mathrm{ml})\end{array}$ \\
\hline 2 & $31 \cdot 1 \pm 4 \cdot 2$ & $75 \cdot 0 \pm 5 \cdot 1$ & 0.41 & $42.9 \pm 15$ \\
\hline 3 & $63.2 \pm 12$ & $86 \cdot 3 \pm 8 \cdot 5$ & 0.73 & $21.6 \pm 9$ \\
\hline 4 & $92.0 \pm 10$ & $65.1 \pm 6.9$ & 1.41 & $27 \cdot 0 \pm 8$ \\
\hline 6 & $90.4 \pm 11$ & $50.7 \pm 2.9$ & 1.78 & $8.5 \pm 2.2$ \\
\hline 8 & $84 \cdot 3 \pm 3 \cdot 3$ & $36.8 \pm 3.6$ & $2 \cdot 29$ & $27.0 \pm 13$ \\
\hline 10 & $150 \pm 14$ & $33 \cdot 0 \pm 2 \cdot 2$ & 4.54 & - \\
\hline 12 & $86 \cdot 7 \pm 30$ & $27.6 \pm 4 \cdot 3$ & $3 \cdot 14$ & $4.1 \pm 0.3$ \\
\hline
\end{tabular}

* Day 1 = day spermatozoa found in vaginal lavage.

Progesterone and 20a-dihydroprogesterone concentrations remained quite constant in androgenized females that were mated but not given PMSG (Table 2). For comparison, and to indicate non-ovarian contributions, the mean progesterone concentration in the sera of 6 androgenized females ovariectomized for 1 week was $4.1 \pm 0.64$ (s.e.m.) ng/ml; the concentration at the end of 2 weeks was $6.3 \pm 0.6 \mathrm{ng} / \mathrm{ml}$. The values for $20 \alpha$-dihydroprogesterone were $1.1 \pm 0.23 \mathrm{ng} / \mathrm{ml}$ at 1 week and $0.84 \pm 0.15 \mathrm{ng} / \mathrm{ml}$ at 2 weeks after ovariectomy.

The lowest serum prolactin concentrations in the mated androgenized females were obtained on the 4th day after mating (Table 2) but because of the large variations the differences from values obtained on other days were not statistically significant $(P>0.05)$.

The hormone levels in androgenized females injected with PMSG but not mated are shown in Table 3. The progesterone level was about the same on Days 2 and 3 and then rose sharply on Day 4; by Day 6 the concentration had again doubled and it remained high through Day 8. 20 $\alpha$ Dihydroprogesterone reached its highest level on Day 6 and then declined to $60 \%$ by Day 10 . Prolactin remained at high concentration through Day 8 but then declined abruptly on Day 9 and remained relatively low on Day 10. 


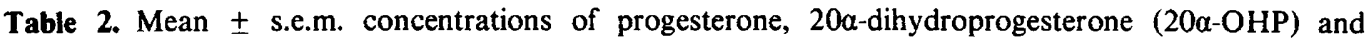
prolactin in the sera of mated androgenized female rats (5/group)

\begin{tabular}{ccccc}
\hline $\begin{array}{c}\text { Days after } \\
\text { mating }\end{array}$ & $\begin{array}{c}\text { Progesterone } \\
(\mathrm{ng} / \mathrm{ml})\end{array}$ & $\begin{array}{c}20 \alpha-\mathrm{OHP} \\
(\mathrm{ng} / \mathrm{ml})\end{array}$ & $\begin{array}{c}\text { Ratio of } \\
\text { progesterone }: 20 \alpha-O H P\end{array}$ & $\begin{array}{c}\text { Prolactin } \\
(\mathrm{ng} / \mathrm{ml})\end{array}$ \\
\hline 3 & $8.3 \pm 1.6$ & $1.16 \pm 0.15$ & 7.15 & $129 \pm 20$ \\
4 & $6.6 \pm 1.0$ & $1.36 \pm 0.32$ & 3.85 & $85 \pm 42$ \\
5 & $5.9 \pm 1.4$ & $1.52 \pm 0.16$ & 2.88 & $130 \pm 33$ \\
6 & $6.8 \pm 1.0$ & $2.28 \pm 0.31$ & 1.96 & $167 \pm 53$ \\
7 & $7.5 \pm 1.5$ & $3.82 \pm 2.16$ & 2.72 & $133 \pm 22$ \\
8 & $5.6 \pm 0.9$ & $2.06 \pm 0.04$ & $3.92 \pm 0.8$ & $146 \pm 18$ \\
\hline $\begin{array}{c}\text { Overall } \\
\text { mean }\end{array}$ & $6.8 \pm 0.4$ & $2.03 \pm 0.4$ & & \\
\hline
\end{tabular}

Table 3. Mean \pm s.e.m. progesterone, $20 \alpha$-dihydroprogesterone $(20 a-O H P)$ and prolactin in the sera of androgenized females injected with 5 i.u. PMSG on Day 1 (5-7/group)

\begin{tabular}{|c|c|c|c|c|}
\hline Days & $\begin{array}{l}\text { Progesterone } \\
\quad(\mathrm{ng} / \mathrm{ml})\end{array}$ & $\begin{array}{c}20 \alpha-\mathrm{OHP} \\
(\mathrm{ng} / \mathrm{ml})\end{array}$ & $\begin{array}{c}\text { Ratio of } \\
\text { progesterone : } 20 \alpha-\mathrm{OHP}\end{array}$ & $\begin{array}{l}\text { Prolactin } \\
(\mathrm{ng} / \mathrm{ml})\end{array}$ \\
\hline 2 & $29.5 \pm 2.8$ & $20.9 \pm 1.5$ & 1.41 & $195 \pm 30$ \\
\hline 3 & $33.8 \pm 3.2$ & $28.4 \pm 6.2$ & $1 \cdot 19$ & $160 \pm 16$ \\
\hline 4 & $137 \pm 12$ & $71.4 \pm 6.0$ & 1.92 & $201 \pm 35$ \\
\hline 5 & $167 \pm 23$ & $71.0 \pm 7.9$ & $2 \cdot 35$ & $275 \pm 50$ \\
\hline 6 & $328 \pm 46$ & $75.4 \pm 6.6$ & $4 \cdot 29$ & $206 \pm 53$ \\
\hline 7 & $248 \pm 43$ & $59 \cdot 3 \pm 2 \cdot 3$ & $4 \cdot 18$ & $190 \pm 47$ \\
\hline 8 & $275 \pm 42$ & $50.7 \pm 6.0$ & 5.42 & $110 \pm 20$ \\
\hline 9 & $84 \pm 17$ & $55.1 \pm 9.2$ & 1.52 & $35 \pm 5 \cdot 2$ \\
\hline 10 & $118 \pm 22$ & $44 \cdot 4 \pm 2 \cdot 3$ & $2 \cdot 66$ & $45 \cdot 5 \pm 8 \cdot 7$ \\
\hline
\end{tabular}

Table 4. Mean \pm s.e.m. concentrations of progesterone, 20 $\alpha$-dihydroprogesterone and prolactin in the sera of androgenized female rats injected with 5 i.u. PMSG and mated on Day 1 (4 rats/group)

\begin{tabular}{|c|c|c|c|c|c|}
\hline Day & $\underset{(h)^{*}}{\text { Time }}$ & $\begin{array}{l}\text { Progesterone } \\
\quad(\mathrm{ng} / \mathrm{ml})\end{array}$ & $\begin{array}{c}20 a-O H P \\
(\mathrm{ng} / \mathrm{ml})\end{array}$ & $\begin{array}{c}\text { Ratio of } \\
\text { progesterone : } 20 \alpha-\mathrm{OHP}\end{array}$ & $\begin{array}{l}\text { Prolactin } \\
\text { (ng/ml) }\end{array}$ \\
\hline 2 & $\begin{array}{l}10: 00 \\
16: 00\end{array}$ & $\begin{array}{l}42 \cdot 9 \pm 1 \cdot 2 \\
25 \cdot 2 \pm 2 \cdot 3\end{array}$ & $\begin{array}{l}31 \cdot 0 \pm 3 \cdot 9 \\
23 \cdot 2 \pm 5 \cdot 7\end{array}$ & $\begin{array}{l}1.38 \\
1.09\end{array}$ & $156 \pm 44$ \\
\hline 3 & $\begin{array}{l}10: 00 \\
16: 00\end{array}$ & $\begin{array}{l}40 \cdot 4 \pm 5 \cdot 1 \\
38 \cdot 0 \pm 3 \cdot 2\end{array}$ & $\begin{array}{l}50.6 \pm 27 \\
20.7 \pm 1.6\end{array}$ & $\begin{array}{l}0.80 \\
1.84\end{array}$ & $\begin{array}{l}231 \pm 60 \\
221 \pm 101\end{array}$ \\
\hline 4 & $\begin{array}{l}10: 00 \\
16: 00\end{array}$ & $\begin{array}{c}108 \pm 10 \\
97 \cdot 1 \pm 8 \cdot 0\end{array}$ & $\begin{array}{l}47 \cdot 7 \pm 5 \cdot 6 \\
33 \cdot 5 \pm 7 \cdot 1\end{array}$ & $\begin{array}{l}2 \cdot 26 \\
2 \cdot 90\end{array}$ & $\begin{array}{l}271 \pm 24 \\
212 \pm 33\end{array}$ \\
\hline 5 & $\begin{array}{l}10: 00 \\
16: 00\end{array}$ & $\begin{array}{l}197 \pm 5 \cdot 3 \\
159 \pm 18\end{array}$ & $\begin{array}{l}78 \cdot 5 \pm 21 \\
46 \cdot 8 \pm 7 \cdot 9\end{array}$ & $\begin{array}{l}2 \cdot 51 \\
3 \cdot 39\end{array}$ & $129 \pm 19$ \\
\hline 6 & $\begin{array}{l}10: 00 \\
16: 00\end{array}$ & $\begin{array}{l}205 \pm 31 \\
156 \pm 10\end{array}$ & $\begin{array}{l}47 \cdot 3 \pm 10 \\
42 \cdot 3 \pm 6 \cdot 6\end{array}$ & $\begin{array}{l}4 \cdot 33 \\
3 \cdot 70\end{array}$ & $\begin{array}{l}197 \pm 57 \\
214 \pm 12\end{array}$ \\
\hline 7 & $\begin{array}{l}10: 00 \\
16: 00\end{array}$ & $27 \overline{-} 22$ & $39 . \overline{-} \pm 0.9$ & $\overline{6 \cdot 81}$ & $229 \pm 73$ \\
\hline 8 & $\begin{array}{l}10: 00 \\
16: 00\end{array}$ & $168 \pm 20$ & $45 \cdot 3 \pm 4 \cdot 8$ & $\begin{array}{c}3 \cdot 71 \\
-\end{array}$ & $87 \pm 18$ \\
\hline 9 & $\begin{array}{l}10: 00 \\
16: 00\end{array}$ & $\begin{array}{l}132 \pm 27 \\
166 \pm 17\end{array}$ & $\begin{array}{l}51.7 \pm 9.8 \\
43.9 \pm 5.7\end{array}$ & $\begin{array}{l}2 \cdot 55 \\
3.78\end{array}$ & $103 \pm 28$ \\
\hline 10 & $\begin{array}{l}10: 00 \\
16: 00\end{array}$ & $\begin{array}{l}126 \pm 30 \\
173 \pm 12\end{array}$ & $\begin{array}{l}73 \cdot 2 \pm 8 \cdot 1 \\
64 \cdot 0 \pm 7 \cdot 5\end{array}$ & $\begin{array}{l}1 \cdot 72 \\
2 \cdot 70\end{array}$ & $\begin{array}{c}93 \pm 26 \\
-\end{array}$ \\
\hline 11 & $\begin{array}{l}10: 00 \\
16: 00\end{array}$ & $\begin{array}{l}71 \cdot 4 \pm 26 \\
47 \cdot 4 \pm 6\end{array}$ & $\begin{array}{l}64 \cdot 1 \pm 13 \\
84 \cdot 1 \pm 10\end{array}$ & $\begin{array}{l}1.11 \\
0.56\end{array}$ & $\begin{array}{l}<30 \\
<30\end{array}$ \\
\hline
\end{tabular}

* Animals were acclimatized to a light schedule of $14 \mathrm{~h} \mathrm{light/day} \mathrm{with} \mathrm{the} \mathrm{lights} \mathrm{on} \mathrm{from} \mathrm{20:00} \mathrm{to} \mathrm{10:00} \mathrm{h}$. 
Each pair of ovaries removed 9 days after injection of PMSG $(\mathbf{N}=7)$ contained an average of 12 corpora lutea and weighed $76.0 \pm 2.9 \mathrm{mg}$; for comparison the paired weight of ovaries of 8 females not injected and containing only follicles was $32.3 \pm 1.9 \mathrm{mg}$.

The hormone levels of mated androgenized females treated with PMSG are shown in Table 4. Two sampling times were used. While there were some differences in hormone concentrations between the two groups these were not statistically significant. After reaching peak values on Day 7 progesterone then declined; 20 $\alpha$-dihydroprogesterone was slightly higher on Days 5, 9, 10 and 11 than on other days. Prolactin concentrations remained high until Day 10; on Day 11 the values were too low to be determined accurately. However, after treatment with PMSG and mating the concentrations were $101 \pm 15 \mathrm{ng} / \mathrm{ml}(\mathrm{N}=5)$ on Day 16 and $111 \pm 13 \mathrm{ng} / \mathrm{ml}$ on Day 21. No implantation sites were found in the animals in this group at autopsy.

\section{Discussion}

The present results clearly indicate that corpora lutea in the ovaries of androgenized females can secrete progesterone for at least 10 days after treatment with PMSG. In contrast, corpora lutea induced by injection of ovine LH, or hCG, fail to sustain progesterone production after about 48 h (Barraclough \& Fajer, 1968; Pang \& Johnson, 1974). After ovulation with LH, progesterone production, as well as high progesterone: $20 \alpha$-dihydroprogesterone ratios, could be sustained until Day 5 by the daily administration of 10 i.u. prolactin, provided that the first dose was given i.v. (Barraclough \& Fajer, 1968). Barraclough \& Fajer (1968) concluded that the gonadotrophin necessary for the maintenance of functional corpora lutea, and which was inadequate in androgenized females, was prolactin.

Subsequent studies have confirmed the importance of prolactin for the production of progesterone by newly formed corpora lutea in normal females (Smith et al., 1976). Furthermore, Smith et al. (1976) have demonstrated that cervical stimulation associated with mating is responsible for the initiation of the diurnal and nocturnal surges in prolactin necessary to maintain progesterone secretion. The rather low levels of prolactin found in the normal pregnant animals in the present study (Table 1) probably can be accounted for by an inappropriate sampling time; $4 \mathrm{~h}$ into the light period would be expected to be a nadir in serum prolactin level (Smith et al., 1975).

Mating is assumed not to occur in androgenized females and thus cannot be invoked to induce prolactin secretion (see references in Dörner, 1977). However, Kramen \& Johnson (1971) found that a large proportion of females, androgenized with 50 or $250 \mu \mathrm{g}$ testosterone propionate, would mate. Brown-Grant (1975) not only found that androgenized females exhibited lordosis and would mate but that some of them ovulated in response to the mating. None of the animals in the present study showed any indication of ovulation unless PMSG had been given, even though in many cases the males had induced vaginal bleeding in the females by repeated intromissions.

PMSG has FSH and LH activity. Administration of this hormone would appear to be able to mimic the surge in LH and FSH which occurs in normal females on the afternoon of pro-oestrus (Butcher et al., 1974). With LH alone, or hCG, the mature follicles in ovaries of androgenized females could be induced to ovulate and the granulosa to luteinize. The loss of granulosa may result in a loss of oestrogen-synthesizing ability, such as occurs in normal females with ovulation, and this loss could secondarily lead to a reduction in the normally high prolactin levels (Mallampati \& Johnson, 1974). Zeilmaker (1964) considered that a loss of oestrogen rather than production of progesterone was the cause for the rather long period of vaginal dioestrus which occurred in androgenized females induced to ovulate with LH. Oestradiol concentrations fall to undetectable levels within $12 \mathrm{~h}$ after an i.v. injection of 20 i.u. PMSG (D. C. Johnson \& T. Sashida, unpublished data). In 3 rats that had been used for mating studies (Table 2), serum 
oestradiol concentrations were determined by immunoassay $48 \mathrm{~h}$ after administration of 5 i.u. PMSG; the level was $38.5 \pm 9.4$ (s.e.m.) pg/ml. In 6 rats killed $72 \mathrm{~h}$ after treatment serum oestradiol varied between 48.3 and $231 \mathrm{pg} / \mathrm{ml}$ with a mean of $142 \mathrm{pg} / \mathrm{ml}$. This high level of oestrogen is probably responsible for maintaining the prolactin level, at least for the first few days after formation of the corpora lutea (Mallampati \& Johnson, 1973). The highest oestrogen levels may also be responsible for the failure to obtain implantation, but this may also be a consequence of the uterine environment which persisted for many weeks prior to treatment with PMSG. Androgenized females have a rather low, but constant, level of oestradiol in the blood (Mallampati \& Johnson, 1974).

In the present study the concentration of prolactin was elevated in the serum until at least Day 9 after injection of PMSG. The variations in prolactin concentrations from day to day and from animal to animal of each group may reflect asynchronous episodic and/or circadian secretion patterns. The reason for the fall in prolactin level in Day 9 in animals given only PMSG (Table 3) or on Day 11 in those mated and given PMSG (Table 4) is unknown. The decrease in the latter was only temporary, however, because values had increased again by 16 and 21 days after injection of PMSG.

Ovaries of androgenized females presumably secrete much less $20 \alpha$-dihydroprogesterone than do those of normal oestrous females (Cortes, McCraken, Lloyd \& Weisz, 1971). Cortes et al. (1971) concluded that the steroid was produced by old corpora lutea of previous cycles and since androgenized females do not have such corpora lutea their production of this hormone would be expected to be low. Barraclough \& Fajer (1968), on the other hand, reported large amounts of $20 \alpha$-dihydroprogesterone in the venous drainage from ovaries in androgenized females given hCG; reserpine administration reduced the level, presumably by increasing the output of prolactin. In the present study $20 \alpha$-dihydroprogesterone was lower in pseudopregnant androgenized females than in normal pregnant animals on Days 2 or 3 but at later times it was higher in the androgenized females. The source of the $20 \alpha$-dihydroprogesterone is not known but it probably comes from the steroidogenically active corpora lutea; the steroid was not present in high concentration in the sera of animals lacking corpora lutea (Table 2).

In conclusion, we interpret the present results to indicate that the LH activity of PMSG causes ovulation and luteinization of mature follicles in androgenized females. The FSH activity of PMSG, probably in concert with LH activity, stimulates the follicular oestrogen-synthesizing system which is responsible for increasing serum oestradiol levels. The oestrogen could then stimulate the hypothalamic-hypophysial axis to increase the secretion of prolactin which is responsible for the maintenance of functional corpora lutea. Other interpretations, including a direct luteotrophic role for oestrogen, are of course possible.

This research was supported in part by a grant from the National Institute on Aging (AG00665). The expert technical assistance of Mrs Muriel Wagoner is gratefully acknowledged.

\section{References}

Barraclough, C.A. (1961) Production of anovulatory sterile rats by single injections of testosterone propionate. Endocrinology 68, 62-67.

Barraclough, C.A. \& Fajer, A.B. (1968) Progestin secretion by gonadotropin-induced corpora lutea in ovaries of androgen-sterilized rats. Proc. Soc. exp. Biol. Med. 128, 781-785.

Brown-Grant, K. (1975) A re-examination of the lordosis response in female rats given high doses of testosterone propionate or estradiol benzoate in the neonatal period. Horm. \& Behav. 6, 351378 .
Butcher, R.L., Collins, W.E. \& Fugo, N.W. (1974) Plasma concentration of LH, FSH, Prolactin, progesterone, and estradiol-17 $\beta$ throughout the 4-day estrous cycle of the rat. Endocrinology 94, 17041710.

Butt, W.R. (1972) The iodination of follicle-stimulating hormone and other hormones for radioimmunoassay. J. Endocr. 55, 453-454.

Cheng, H.C. \& Johnson, D.C. (1973/74) Serum estrogens and gonadotropins in developing androgenized and normal female rats. Neuroendocrinology 13, $357-365$. 
Cortes, V., McCraken, J.A., Lloyd, C.W. \& Weisz, J. (1971) Progestin production by the ovary of the testosterone-sterilized rat treated with an ovulatory dose of $\mathbf{L H}$, and the normal, proestrous rat. Endocrinology 89, 878-883.

Dörner, G. (1977) Hormone dependent differentiation, maturation and function of the brain and sexual behavior. Endokrinologie 69, 306-320.

Gay, V.L., Midgley, A.R., Jr \& Niswender, G.D. (1970) Patterns of gonadotrophin secretion associated with ovulation. Fedn Proc. Fedn Am. Socs exp. Biol. 29, 1880-1887.

Grotjan, H.E., Jr \& Johnson, D.C. (1976) Temporal variations in reproductive hormones in the immature male rat. Proc. Soc. exp. Biol. Med. 152, 381-384.

Johnson, D.C. (1963) Hypophysial LH release in androgenized female rats after administration of sheep brain extracts. Endocrinology 72, 832-836.

Johnson, D.C. (1972) Sexual differentiation of gonadotropin patterns. Am. Zoologist 12, 193-205.

Kramen, M.A. \& Johnson, D.C. (1971) Mating, fertilization and ovum viability in the anovulatory, persistent-estrus rat. Fert. Steril. 22, 745-753.

Mallampati, R.S. \& Johnson, D.C. (1973) Serum and pituitary luteinizing hormone follicle stimulating hormone and prolactin levels in gonadectomized male, female and androgenized female rats treated with oestradiol benzoate. J. Endocr. 59, 209-216.

Mallampati, R.S. \& Johnson, D.C. (1974) Gonadotropins in female rats androgenized by various treatments: prolactin as an index to hypothalamic damage. Neuroendocrinology 15, 255-266.

Pang, C.N. \& Johnson, D,C. (1974) A method for the preparation of steroid-protein antigens for use in immunoassay of steroids. Steroids 23, 203-219.

Segal, S.J. \& Johnson, D.C. (1959) Inductive influence of steroid hormones on the neural system: ovulation controlling mechanisms. Archs Anat. microsc. Morphol. exp. 4, 261-273.

Smith, M.S., Freeman, M.W. \& Neill, J.D. (1975) The control of progesterone secretion during the estrous cycle and early pseudopregnancy in the rat: prolactin, gonadotropin and steroid levels associated with rescue of the corpus luteum of pseudopregnancy. Endocrinology 96, 219-225.

Smith, M.S., McLean, B.K. \& Neill, J.D. (1976) Prolactin: the initial luteotropic stimulus of pseudopregnancy in the rat. Endocrinology 98, 13701375.

Zeilmaker, G.H. (1964) Aspects of the regulation of corpus luteum function in androgen-sterilized female rats. Acta endocr., Copenh. 46, 571-577.

Received 10 October 1978 